\title{
Utilizing the Functions of Hydrocolloids as Fat Mimetic to Enhance the Properties of Low-fat Domiati Cheese
}

\author{
Tareq Alnemr ${ }^{1,2 \#}$, Ahmed Helal ${ }^{3 \#}$, Amal Hassan ${ }^{1}$ and Khaled Elsaadany ${ }^{1}$ \\ ${ }^{1}$ Department of Dairy Science and Technology, Faculty of Agriculture, Alexandria University, 21526, Alexandria, Egypt \\ ${ }^{2}$ King Faisal University, Department of food \& Nutrition Science, 31982, Al-Ahsaa KSA \\ ${ }^{3}$ Department of Food and Dairy Sciences and Technology, Faculty of Agriculture, Damanhour University, 22516, Damanhour, Egypt \\ \#These authors contributed equally to this work
}

\begin{abstract}
Regarding the rising demand of eating healthy displayed by consumers over the past few years, dairy market has been increasing its supply in producing low-fat cheese. As well known, the reduction of fat in cheese milk causes a significant decrease in organoleptic properties and cheese yield, thus dairy scientists have a continuous challenge to counteract these defects and satisfy the consumer's requests. This work was undertaken to investigate the possibilities to improve the characteristics of low-fat Domiati cheese by using hydrocolloids as fat mimetic. Mixture of kappa carrageenan, locust bean and xanthan gums have been added to chesses milk. Upon using different concentrations of Hydrocolloids, low-fat cheese showed a significant increase in the physiochemical characteristics, yield, and moisture. Furthermore, organoleptic properties obtained were both highly acceptable and comparable to full-fat cheese. These positive effects were also sustained during the 75 days ripening period where sensory scores were closely similar to those obtained from full-fat cheese.
\end{abstract}

Keywords: Domiati cheese; Low-fat; Hydrocolloids; Fat mimetic; Cheese yield

Abbreviations: FFC: Full-fat Cheese; LFC: Low-fat Cheese; LFH: Low-fat Cheese Containing Kappa Carrageenan Locust Bean and Xanthan Gums

\section{Highlights}

a. K-carrageenan, locust bean and xanthan compensate for the fat reduction effects.

b. Hydrocolloids could be used as fat mimetic in the production of low-fat cheese.

c. Mixture of hydrocolloids improve the yield recovery in low-fat Domiati cheese.

\section{Introduction}

Domiati cheese (Gbnah Beeda) is one of the most unique cheeses both in Egypt and the Middle East. It is usually made from bovine milk where the milk is salted at the first step of its manufacturing process, Sodium chloride are usually added in ranges of $5 \%$ to $14 \%$ of milk (W/W) depending on the consumer preferences and manufactures season. Based on the huge production and consumption rate of this cheese in the Egyptian markets (about 75\% of total cheese production), Domiati cheese is rated the most popular soft white pickled cheese in Egypt [1-3]. Over the last decade, as a result of growing healthy interest of consumers and the increased awareness from the health and nutrition associations and society, the market demand of reduced-fat products in general has become more than just a trend. Therefore, the production of low-fat cheese has been a constant preoccupation, that resulted in the significant growth of low-fat cheese production and thereby the overall growth of the low-fat cheese market [4,5]. Fats are well known to play a critical role in the flavour, texture, and appearance of food products. It quickly becomes obvious that developing low-fat products with a quality matching that of their full-fat types is a quite difficult task when one is replacing fat with alternative ingredients [6]. When dealing with cheese, reducing, or lowering its fat content adversely affects both its flavour and texture, therefore the development of low-fat cheese with comparable properties of full-fat cheese is often challenging $[7,8]$. In efforts to increase the likeability of low-fat cheese and overcome these defects, various suggestions and trials have been proposed. Fat replacers have been strongly recommended, regarding their effects on cheeses composition, component recoveries, cheeses yield, and yield recovery [9].

Fat replacers play a similar role of fat in cheese with a reduction in the caloric value which thereby possibly decreases the consumer's susceptibility to coronary heart diseases [10]. Generally, the ingredients of fat replacers are fats, proteins, or carbohydrates, giving similar physiochemical properties as milk fat [11], they are often categorized into two groups; Fat substitutes which are fat based indigestible macromolecules with a caloric value lower than that of milk fat, or fat mimetic often called protein and / or carbohydrate based fat replacers which are polar, water sol compounds having different chemical structures in contrast to fat [4]. Hydrocolloids are one of the biopolymers derived from natural sources such as plant, animals or microorganisms. When the biopolymer is carbohydrate based then it is often referred to as Hydrocolloids; due to their large number of hydroxyl groups, hydrocolloids demonstrate high hydrophilic properties and affinity for binding to water molecules. Owing to their structure and physiochemical properties to mimetic milk fat and their functional properties such as thickening, gelling, emulsifying and stabilization, the using of hydrocolloids as fat replacers has been extended in manufacturing cheese and other foods $[12,13]$.

Hydrocolloids have been used in different dairy products for different functions. For example, Abd Elhamid [14] used carboxymethyl cellulose to enhance the properties of low-fat Domiati cheese; while

*Corresponding author: Ahmed Helal, Department of Food and Dairy Sciences and Technology, Faculty of Agriculture, Damanhour University, 22516, Damanhour, Egypt Tel: +201002908422, Fax: +20453318537; E-mail: ahmed.helal@damanhour.edu.eg

Received October 14, 2016; Accepted November 15, 2016; Published November 21, 2016

Citation: Alnemr T, Helal A, Hassan A, Elsaadany K (2016) Utilizing the Functions of Hydrocolloids as Fat Mimetic to Enhance the Properties of Low-fat Domiati Cheese. J Food Process Technol 7: 637. doi: 10.4172/2157-7110.1000637

Copyright: $\odot 2016$ Alnemr T, et al. This is an open-access article distributed unde the terms of the Creative Commons Attribution License, which permits unrestricted use, distribution, and reproduction in any medium, provided the original author and source are credited. 
Romeih et al. [6] used different commercial hydrocolloids as fat replacers to produce Low-fat white-brined cheese. To counteract the negative effects of fat reduction by using guar gum and xanthan gum as fat replacers in Low-fat Mozzarella Cheese [10] and using carrageenan in low-fat Oaxaca cheese [13]. Furthermore, the effect of using proteinbased and carbohydrate-based fat replacer on rheological and sensory properties low-fat fresh Kashar cheese have been demonstrated by Koca and Metin [9], in addition, low-fat white pickled cheese were produced by using some protein or carbohydrate based fat mimetic [4], evaluating different fat replacers like modified corn starch and xanthan gum on low-fat Mozzarella cheese [15]. Recently, hydrocolloids were also used to stabilize structure, enhance viscosity and alter textural characteristics of different types of cheese such as in processed cheese with vegetable fats to enhance the rheological properties [16]. Jana et al. [17] studied the effect of using xanthan gum-locust bean gum, carrageenan on texture profile of casein based Mozzarella cheese analogue, while Černíková et al. [18] used them in processed cheese as a replacement of traditional emulsifying salts

Based on our knowledge, there are no recent studies about using this mixture of hydrocolloids (K-carrageenan, locust bean and xanthan) with low-fat Domiati cheese; therefore, the main objective of this study is to evaluate the functionality of hydrocolloids throughout storage as fat mimetic in low-fat Domiati cheese.

\section{Materials and Methods}

\section{Cheese making procedure}

Five different treatments of cheese were made, each treatment was manufactured in triplicate, and six litres of milk were used for each replicate. Full-fat Domiati cheese (FFC) was manufactured using fullfat milk purchased from a local farm (Alexandria, Egypt) (T.S\% $=11.6$ \pm 0.3 , Fat $\%=3.5 \pm 0.13$, Protein $\%=3.1 \pm 0.04, \mathrm{pH}=6.7 \pm 0.01)$. For production of Low-fat Domiati cheese, the milk was standardized to $2 \%$ fat $(\mathrm{T} . \mathrm{S} \%=9.9 \pm 0.2, \mathrm{Fat} \%=2 \pm 0.16$, Protein $\%=3.1 \pm 0.05, \mathrm{pH}$ $=6.7 \pm 0.01)$ and was divided into four vats. The first one was (LFC) continuously processed as full-fat cheese without any modifications, while in the second to fourth vat (LFH1, LFH2 and LFH3) conventional production techniques have been followed by adding the mixture of hydrocolloids (Kappa carrageenan, Locust bean and Xanthan gums) supplied by Cargill France SAS (Paris, France) with ratio of 60:20:20 respectively in the standardized milk to have a final concentration of $0.25,0.5$ and $0.75 \mathrm{~g} / \mathrm{kg}$ of milk. Cheese was made by traditional methods as previously described by Abou-Donia [19]; milk was heated to $38^{\circ} \mathrm{C}$, and then supplemented with $8 \%$ sodium chloride. In case of using the hydrocolloids, the mixture of Kappa carrageenan, and Locust bean and Xanthan gums was then added. Agitation was gradually continued for $5 \mathrm{~min}$ to complete mixing. The milk was then pasteurized at $65^{\circ} \mathrm{C}$ for $25 \mathrm{~min}$ and then cooled to $40^{\circ} \mathrm{C}$ and supplemented with $0.02 \% \mathrm{w} / \mathrm{w}$ of $\mathrm{CaCl}_{2}$, and inoculation of the mesophilic mixed culture containing Streptococcus thermophilus + Lactobacillus delbrueckii ssp. bulgaricus (Danisco, Kopenhag, Denmark) the milk was held at the same temperature for approximately $30 \mathrm{~min}$ for starter maturation. The milk was coagulated using the calf rennet (Chr. Hansen, Denmark), after dissolving in water. After 2-3 hours of coagulation, each curd was then transferred to a small mould under an initial pressure for whey expulsion for 24 hours. After pressing, the curd was cut into small blocks, placed in airtight plastic containers, and covered with a $12 \%$ pasteurized filtered brine solution. The blocks were stored at $23^{\circ} \mathrm{C}$ to $25^{\circ} \mathrm{C}$ for $24 \mathrm{~h}$, and then all cheese containers were sealed and stored in a cold room at $5^{\circ} \mathrm{C}$ to $6^{\circ} \mathrm{C}$ for the ripening period of 75 days.

\section{Cheese analysis}

Moisture of different cheese treatments were determined by using oven drying method [20]. Fat content of milk and cheese samples were determined by the Gerber method [21]. Protein contents of the milk and cheese were determined by measuring total nitrogen using the Kjeldahl method [20] by converting the value to protein percentage using the factor of 6.38. The $\mathrm{pH}$ of milk and cheese samples was measured using a digital pH meter (Hanna pH 211, Hanna instruments, Woonsocket, RI, USA).

Superficial yields were elaborated as the weight of cheese divided by the weight of used milk [22]. All the analysis measurements were done in triplicate at days of $0,15,30,45,60$ and 75 of ripening.

\section{Sensory evaluation}

In the present study Domiati cheese products were evaluated targeted appearance, flavour, body texture and odour by regular score panel according to the scoring sheet of Abdou et al. [23] and the total scores were presented. Twenty panellists had evaluated the cheese in two consumers sensory test panel, for organoleptic assessment of the cheeses at days of $0,15,30,45,60$ and 75 of ripening. Each panellist evaluated all samples during all storage period and has been instructed with the regular protocols of test panel.

\section{Statistical analysis}

The experimental design was completely randomized design (CRD) in factorial arrangement using three replications; all data are presented as mean \pm SD for three replicates for each sample. The Students' tests were performed using XLSTAT 2007 (Addinsoft 1995e2007, New York, USA) when data were compared with controls. Univariate analysis of variance (ANOVA) was applied using Stat graphics 16.1.11 (Stat Point Technologies, Inc., Virginia, USA) when multiple comparisons were performed. The differences were considered significant at $\mathrm{P}<0.05$.

\section{Results and Discussion}

\section{Effect of fat mimic on the physicochemical attributes of cheese}

Milk fat is one of the major components in milk and most important components in cheeses as well. It is trapped in the protein matrix during cheeses making [24]. Table 1 shows fat percentage and protein content for full- and low-fat Domiati cheese after manufacturing and during ripening period. When fat level in cheese milk was reduced from $3.5 \%$ to $2 \%$, fat contents in cheese reduced significantly. Full-fat cheese milk showed the highest fat cheese content among all treatments, whereas low-fat cheeses with or without hydrocolloids showed lower significant fat content, in addition, the hydrocolloids significantly attributed to the fat content of cheese treatments, using different levels of fat mimetic (Kappa carrageenan, Locust bean and Xanthan gums) increased the fat content respect to the control low-fat cheese; however there were no significant differences among the different concentrations of fat replacers. Similar results were reported by Sattar et al. [10] and Salazar et al. [25]. During ripening period, the fat content of all cheeses increased significantly (Table 1). This increase was continuously achieved until the end of ripening days. This phenomenon may be due to the reduction of moisture content during storage of ripening period $[8,26]$. In case of hydrocolloids treatments; however, the fat content increased with ripening period, the values were significantly lower than in the control low-fat cheese starting after 30 days of storage and continued with same trend until the 75 days of storage. This could be a result of higher water binding capacity of the added hydrocolloids, and the lower rate of moisture losses during ripening. This variation 


\begin{tabular}{|c|c|c|c|c|c|c|c|}
\hline & \multirow{2}{*}{$\begin{array}{l}\text { Cheese } \\
\text { treatments }\end{array}$} & \multicolumn{6}{|c|}{ Ripening period (days) } \\
\hline & & 0 & 15 & 30 & 45 & 60 & 75 \\
\hline \multirow{5}{*}{ Fat $\%$} & FFC & $14.32 \pm 0.22$ & $15.62 \pm 0.38$ & $16.47 \pm 0.45$ & $16.66 \pm 0.33$ & $17.34 \pm 0.23$ & $18.14 \pm 0.17$ \\
\hline & LFC & *11.26 \pm 0.06 & *11.87 \pm 0.18 & *12.20 \pm 0.19 & *13.80 \pm 0.07 & *14.01 \pm 0.17 & *14.41 \pm 0.23 \\
\hline & LFH1 & $* 11.40 \pm 0.33^{\mathrm{ab}}$ & *11.65 $\pm 0.31^{\mathrm{abcd}}$ & *11.85 $\pm 0.17^{\text {abcde }}$ & ${ }^{*}, * * 12.40 \pm 0.12^{\text {cdefg }}$ & ${ }^{*}, * * 13.07 \pm 0.14^{\mathrm{fg}}$ & ${ }^{*} 13.38 \pm 0.43^{g}$ \\
\hline & LFH2 & ${ }^{*}, * * 11.70 \pm 0.18^{\mathrm{abcd}}$ & $* 11.58 \pm 0.08^{\mathrm{abc}}$ & $* 11.90 \pm 0.08^{\text {abcdef }}$ & ${ }^{*},{ }^{*} 12.33 \pm 0.23^{\text {bcdefg }}$ & ${ }^{*},{ }^{* *} 12.85 \pm 0.46^{\mathrm{efg}}$ & ${ }^{*},{ }^{* *} 13.36 \pm 0.23^{g}$ \\
\hline & LFH3 & ${ }^{*}, * * 11.76 \pm 0.17^{\mathrm{abcd}}$ & *11.81 $\pm 0.27^{\text {abcde }}$ & *12.38 $\pm 0.17^{\text {cdefg }}$ & ${ }^{*}, * * 12.50 \pm 0.24^{\text {defg }}$ & ${ }^{*}, * * 12.28 \pm 0.16^{\text {bcdefg }}$ & ${ }^{*},{ }^{* *} 13.35 \pm 0.21^{9}$ \\
\hline \multirow{5}{*}{ Protein \% } & FFC & $18.50 \pm 0.10$ & $18.18 \pm 0.16$ & $17.25 \pm 0.16$ & $16.40 \pm 0.27$ & $15.25 \pm 0.12$ & $14.77 \pm 0.12$ \\
\hline & LFC & *22.31 \pm 0.07 & *21.80 \pm 0.17 & $* 21.33 \pm 0.21$ & *20.99 \pm 0.13 & $* 19.30 \pm 0.23$ & *18.77 \pm 0.12 \\
\hline & LFH1 & ${ }^{\star} 22.46 \pm 0.14^{g}$ & *21.28 $\pm 0.25^{\text {defg }}$ & ${ }^{*} 21.48 \pm 0.16^{\text {abcdef }}$ & ${ }^{\star} 20.76 \pm 0.20^{\mathrm{abcd}}$ & $* 19.29 \pm 0.27^{\mathrm{abc}}$ & *18.63 \pm 0.26 ab \\
\hline & LFH2 & ${ }^{*} 22.27 \pm 0.05^{\mathrm{fg}}$ & ${ }^{\star} 21.31 \pm 0.18^{\text {defg }}$ & ${ }^{\star} 21.22 \pm 0.12^{\text {cdefg }}$ & ${ }^{\star} 20.48 \pm 0.16^{\text {abcdef }}$ & $* 19.31 \pm 0.17^{\mathrm{abc}}$ & *18.14 $\pm 0.18^{a}$ \\
\hline & LFH3 & ${ }^{\star} 21.82 \pm 0.15^{\mathrm{efg}}$ & ${ }^{*} 21.45 \pm 0.17^{\text {defg }}$ & ${ }^{\star} 20.81 \pm 0.17^{\text {bcdefg }}$ & ${ }^{*} 20.22 \pm 0.24^{\mathrm{abcde}}$ & *19.13 $\pm 0.29^{\mathrm{abcd}}$ & *18.08 $\pm 0.06^{\mathrm{a}}$ \\
\hline
\end{tabular}

Data are means $\pm S D ; n=3$

* indicates significantly different $(P<0.05)$ with respect to the first control $(F F C)$ in the same time of ripening

** indicates significantly different $(P<0.05)$ with respect to the second control $(L F C)$ in the same time of ripening

${ }^{a-g}$ Different letters following means in cheese with hydrocolloids treatments denote significant differences $(p>0.05)$

Table 1: Fat and protein content for different types of Domiati cheese during 75 days of ripening.

was clear by calculating the fat increasing in rate from 1 to 75 days, as it were $27.97 \%, 17.36 \%, 14.18 \%$ and $13.52 \%$ for LFC, LFH1, LFH2 and LFH3 respectively. Regarding protein content, reducing fat content in cheeses led to an increase in protein content. Full-fat cheese showed the lowest protein content $(18.50 \pm 0.10)$ among all samples and this may be due to the higher moisture content. Some other studies have previously reported similar results [4,9,14,27-29]. Adding mixture of hydrocolloids as fat mimetic didn't significantly affect the cheese protein content.

Among all cheeses samples, a decrease in proteins content was observed with the increase in the ripening period as a result of degradation, where a significant decrease was observed after 45 days of storage. Comparing the cheese containing fat mimetic as fat replacers with low-fat cheese, the protein decreasing rate was somewhat higher regarding the high moisture content, which generally increases the enzyme activity $[4,6]$. One of the important characteristics of cheese curd is the moisture content, which affects many other factors either physically such as yield and texture or chemically and nutritional values based on dry weight. Table 2 shows the moisture content and their behaviour during the ripening period. Through the presented of differences in moisture content between the full-fat cheese and the low-fat cheese, inverse relationship between fat content and moisture content was observed. This relationship could be attributed to their nitrogen content, where higher protein content of reduced-fat cheeses may have contributed to an increased water-binding capacity of the cheese matrix, subsequently increasing moisture content $[4,6,14]$. Furthermore, moisture content had been improved by the effects of adding the mixture of hydrocolloids. This significant increase is due to higher water binding capacity of the Kappa carrageenan, Locust bean and Xanthan gums $[7,12,15,16]$. In addition, the highest concentration of fat replacers ( $0.75 \mathrm{~g} / \mathrm{kg}$ of milk) showed the highest moisture content among all cheese treatments; whereas increase the level of hydrocolloids mixture, the moisture contents increased non-significantly [10].

During the ripening period as shown in Table 2, somewhat decreases of moisture content among all cheeses samples have been observed until the end of ripening period. As an indicator of cheese acidity, the influence of fat mimetic on the mean $\mathrm{pH}$ values is shown in Table 2 . The $\mathrm{pH}$ values have been analysed after the cheese manufacturing and continuously monitored until the end of ripening to follow the changes in cheeses acidity.

Reducing fat content in cheese milk didn't significantly affect the
$\mathrm{pH}$ value, in addition, there was somewhat lower values in case of using different concentration of fat mimetic but was not significant, similar studies reported that using Kappa carrageenan, Locust bean and Xanthan gums didn't have significant effect on cheese $\mathrm{pH}$. Kavas et al. [4], Sattar et al. [10] and Hanáková et al. [16] found similar results in their studies about different fat replacers. During ripening, there was a slight decreasing pattern of $\mathrm{pH}$ values among all cheeses, this decrease was very clear after 45 days of ripening and continues till the end of ripening especially in case of adding hydrocolloids as fat mimetic. The decreasing of $\mathrm{pH}$ value during ripening is a result of the chemical composition change [30]. The gradual decrease of $\mathrm{pH}$ value during ripening may be attributed to combination of the content of mineral content such as calcium and phosphorus, furthermore, the ratio of salt to moisture is also a very important factor [31]. In addition, during the ripening of cheese, changes of biochemistry may have occurred due to the different proteolysis and metabolism of the milk components and the residual lactose in the chesses curd, these changes are important factors that affect the $\mathrm{pH}$ value during ripening of cheese [32]. Since the moisture content is important to the different chemical reactions that occur in cheese curd during ripening, and as well-known that cheese with fat mimetic retained higher moisture than corresponding treatments without adding, thus could explain the noticed higher decrease of $\mathrm{pH}$ value in these chesses treatments. These changes in $\mathrm{pH}$ values during the ripening could partly explain that the decrease of moisture content might be due to the concentration of curd as a result of developed acidity during ripening period which helps to eject the whey from the curd $[33,34]$.

\section{Effect of fat mimic on the attitude of cheese yield}

Cheese yield is a very important parameter in the cheese industry and it highly affects the manufactures decision in choosing different additives, fat replacers, and other ingredients.

It's well known that cheese is a concentrated product mainly formed of proteins and fats. As a consequence, cheeses yield is highly affected by fats and casein content of the milk [35]. Cheeses yield as presented in Figure 1 showed a significant reduction with decreasing fats content in cheeses, $28.87 \pm 0.42 \%$ and $26.89 \pm 0.14 \%$ for full and low-fat cheese respectively. Although it is true that fats in cheese are replaced by moisture, but an overall reduction in yield is inevitable in the production of cheese from low-fat milk because the total amount of fats removed is not equal to the amount of moisture added $[6,36]$. In addition, the increase of fats content of milk in case of full-fat 


\begin{tabular}{|c|c|c|c|c|c|c|c|}
\hline & \multirow{2}{*}{$\begin{array}{c}\text { Cheese } \\
\text { treatments }\end{array}$} & \multicolumn{6}{|c|}{ Ripening period (days) } \\
\hline & & 0 & 15 & 30 & 45 & 60 & 75 \\
\hline \multirow{5}{*}{ Moisture \% } & FFC & $60.28 \pm 0.13$ & $58.47 \pm 0.17$ & $57.69 \pm 0.33$ & $56.15 \pm 0.19$ & $54.19 \pm 0.24$ & $53.30 \pm 0.55$ \\
\hline & LFC & $58.82 \pm 0.14$ & $57.52 \pm 0.44$ & $55.59 \pm 0.51$ & $53.65 \pm 0.50$ & $51.99 \pm 0.69$ & $50.66 \pm 0.33$ \\
\hline & LFH1 & ${ }^{* *} 60.67 \pm 0.41^{\mathrm{def}}$ & $* * 58.67 \pm 0.56^{\text {bcdef }}$ & $56.70 \pm 0.56^{\mathrm{abc}}$ & ** $55.40 \pm 0.45^{\mathrm{ab}}$ & ${ }^{* *} 54.40 \pm 0.35^{\mathrm{ab}}$ & ${ }^{* *} 52.55 \pm 0.44^{\mathrm{a}}$ \\
\hline & LFH2 & ${ }^{*},{ }^{* *} 61.90 \pm 0.26^{\mathrm{ef}}$ & $*{ }^{* *} 59.50 \pm 0.23^{\text {cdef }}$ & ${ }^{*},{ }^{* *} 58.71 \pm 0.35^{\text {bcdef }}$ & ${ }^{*}, * * 57.22 \pm 0.13^{\mathrm{abcd}}$ & ${ }^{*}, * \star 55.62 \pm 0.33^{\mathrm{ab}}$ & ${ }^{* *} 53.96 \pm 0.17^{a}$ \\
\hline & LFH3 & ${ }^{*},{ }^{* *} 63.22 \pm 0.30^{f}$ & ${ }^{*},{ }^{* *} 60.48 \pm 0.22^{\text {def }}$ & $*, * * 59.55 \pm 0.44^{\text {cdef }}$ & ${ }^{*},{ }^{* *} 58.51 \pm 0.44^{\text {bcdef }}$ & $*{ }^{* *} 57.60 \pm 0.33^{\text {abcde }}$ & ${ }^{*},{ }^{* \star} 56.76 \pm 0.43^{\mathrm{abc}}$ \\
\hline \multirow{5}{*}{$\mathrm{pH}$} & FFC & 5.33 & 5.29 & 5.25 & 5.12 & 5.09 & 5.04 \\
\hline & LFC & 5.29 & 5.25 & 5.16 & 5.14 & 5.06 & 5.01 \\
\hline & LFH1 & *5.19! & $*,{ }^{* *} 5.13^{\mathrm{fghi}}$ & $*,{ }^{* *} 5.00^{\text {cdefghi }}$ & $*,{ }^{* *} 4.98^{\text {bcdefgh }}$ & ${ }^{*},{ }^{* *} 4.92^{\mathrm{abcdef}}$ & ${ }^{*},{ }^{* *} 4.86^{\mathrm{abc}}$ \\
\hline & LFH2 & *5.17 hi & ${ }^{*}, * * 5.14^{\mathrm{ghi}}$ & ${ }^{*},{ }^{* *} 5.08^{\text {efghi }}$ & $*, * * 4.93^{\text {abcdefg }}$ & ${ }^{*},{ }^{* *} 4.88^{\mathrm{abcd}}$ & ${ }^{*}, * * 4.79^{\mathrm{ab}}$ \\
\hline & LFH3 & *5.22' & ${ }^{*},{ }^{* \star} 5.12^{\mathrm{fghi}}$ & ${ }^{*}, * * 4.98^{\text {bcdefgh }}$ & ${ }^{*}, * * 4.90^{\text {abcde }}$ & ${ }^{*},{ }^{* *} 4.80^{\mathrm{abc}}$ & ${ }^{*}, * \star 4.72^{\mathrm{a}}$ \\
\hline
\end{tabular}

Data are means $\pm \mathrm{SD} ; \mathrm{n}=3$

* indicates significantly different $(P<0.05)$ with respect to the first control $(F F C)$ in the same time of ripening.

** indicates significantly different $(P<0.05)$ with respect to the second control $(L F C)$ in the same time of ripening.

${ }^{a-g}$ Different letters following means in cheese with hydrocolloids treatments denote significant differences $(p>0.05)$.

Table 2: Moisture content and $\mathrm{pH}$ values for different types of Domiati cheese during 75 days of ripening.

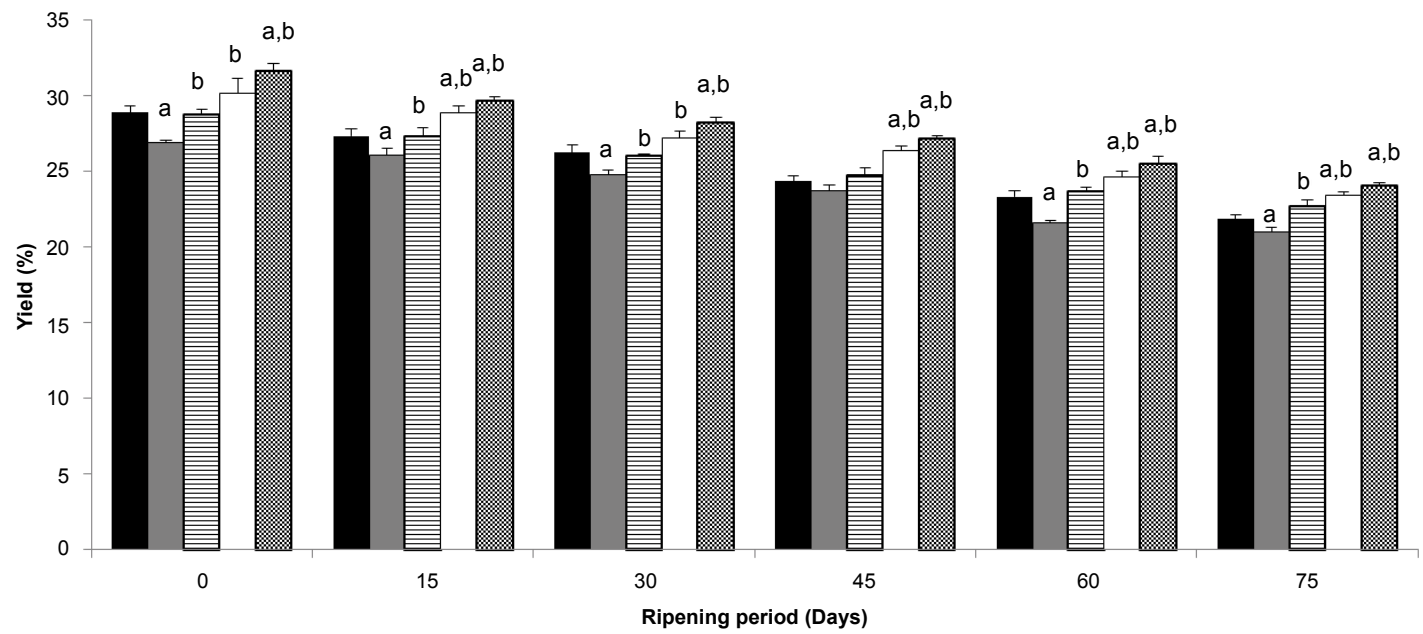

a indicates significantly different $(P<0.05)$ with respect to the FFC in the same time of ripening

${ }^{b}$ indicates significantly different $(P<0.05)$ with respect to the LFC in the same time of ripening

Figure 1: Mean of yield of FFC (black bars), LFC (grey bars), LFH1 (striped bars), LFH2 (white bars) and LFH3 (checkered bars) Domiati cheese during 75 days of ripening. Results are expressed as percentage. Data are means $\pm \operatorname{SD}(n=3)$

cheese leads to reduction of whey syneresis from cheese curd during manufacturing $[37,38]$. The cheeses yield Increased significantly and proportionally by adding fat mimetic with different concentration to reach $28.74 \pm 0.33 \%, 30.14 \pm 1 \%$ and $31.57 \pm 0.52 \%$ for LFH1, LFH2 and LFH3, respectively. This influence may be related to the high waterbinding property of the mixture of Kappa carrageenan, locust been and xanthan gums $[12,16]$. The uses of hydrocolloids as fat replacers have been known for their effects in improving both texture and yield $[10,14,28,39]$.

However the effects of concentration was not significant between the mixture of Kappa carrageenan, locust been and xanthan gums treatments, but the LFH3 which exhibited the highest concentration of hydrocolloids ( $0.75 \mathrm{~g} / \mathrm{kg}$ of milk) showed a significantly higher yield value in respect to the full-fat cheese directly after manufacturing and even during the ripening period. On the other hand, observation of cheese yield during the ripening period among all cheese samples showed a significant gradual decrease as the ripening period progressed, which agrees with those data reported by Abdel-kader [33], Kebary et al. [40] and Mehanna et al. [41]. The enhancement effect of adding selected hydrocolloids on yield were continued during and at the end of ripening. The low-fat cheese with the added mixture of Kappa carrageenan, locust been and xanthan kept their attitude and presented significantly higher yield values and lower decreasing rates than the control low-fat cheese and even than high fat cheese in some cases. In addition, yield values were also in proportion with the hydrocolloids concentration, where the end of ripening period ( 75 days) the cheese yield was $22.65 \pm 0.46 \%, 23.41 \pm 0.19 \%$ and $24.00 \pm 0.18 \%$ for LFH1, LFH2 and LFH3, respectively; while it was $21.81 \pm 0.32$ and $20.98 \pm$ 0.32 for high and low-fat cheese respectively.

\section{Effect of fat mimic on the sensory attitude of cheeses}

Even though Domiati cheese is often consumed after ripening, sensory evaluation directly after production is very important and reflects its sensory attitude during the ripening period. The results of sensory evaluation out of 100 scores for cheese are presented in Table 3 , cheeses with lower fats usually have less pronounced flavour, possibly because of its dilution in reduced and low-fat cheeses because of excessive moisture retention $[24,42]$. The fats in cheese are responsible for most of the flavours [8] therefore when fats are decreased, the cheeses flavour decreases $[4,14]$. 
Citation: Alnemr T, Helal A, Hassan A, Elsaadany K (2016) Utilizing the Functions of Hydrocolloids as Fat Mimetic to Enhance the Properties of Lowfat Domiati Cheese. J Food Process Technol 7: 637. doi: 10.4172/2157-7110.1000637

Page 5 of 6

\begin{tabular}{|c|c|c|c|c|c|c|}
\hline \multirow{2}{*}{ Cheese Treatments } & \multicolumn{6}{|c|}{ Ripening period (days) } \\
\hline & 0 & 15 & 30 & 45 & 60 & 75 \\
\hline FFC & $83.70 \pm 4.74^{\text {abcdef }}$ & $84.20 \pm 3.29^{\text {abcdef }}$ & $86.70 \pm 5.37^{\text {bcdefgh }}$ & $89.65 \pm 4.59^{\text {efgh }}$ & $91.15 \pm 2.60^{g h}$ & $89.85 \pm 5.15^{\text {efgh }}$ \\
\hline LFC & $76.60 \pm 4.41^{a}$ & $77.00 \pm 2.85^{a}$ & $82.30 \pm 5.75^{\mathrm{abcd}}$ & $83.95 \pm 3.80^{\text {abcdef }}$ & $86.70 \pm 3.88^{\text {bcdefgh }}$ & $80.65 \pm 5.44^{\mathrm{abc}}$ \\
\hline LFH1 & $80.65 \pm 4.64^{\mathrm{abc}}$ & $84.05 \pm 3.59^{\text {abcdef }}$ & $84.65 \pm 3.91^{\mathrm{abcdef}}$ & $87.70 \pm 2.83^{\text {cdefgh }}$ & $89.75 \pm 3.20^{\text {efgh }}$ & $90.15 \pm 3.01^{\mathrm{fgh}}$ \\
\hline LFH2 & $83.55 \pm 4.22^{\mathrm{abcde}}$ & $86.15 \pm 4.69^{\text {bcdefgh }}$ & $88.80 \pm 2.61^{\text {defgh }}$ & $89.70 \pm 4.39^{\text {efgh }}$ & $91.00 \pm 2.32^{\mathrm{gh}}$ & $92.90 \pm 3.52^{h}$ \\
\hline LFH3 & $79.75 \pm 5.21^{\mathrm{ab}}$ & $79.65 \pm 5.91^{\mathrm{ab}}$ & $83.50 \pm 3.07^{\text {abcde }}$ & $83.60 \pm 4.52^{\mathrm{abcde}}$ & $85.05 \pm 3.52^{\text {bcdefg }}$ & $88.05 \pm 5.61^{\text {defgh }}$ \\
\hline
\end{tabular}

Table 3: Sensory evaluation out of 100 scores of different types of Domiati cheese during 75 days of ripening.

In addition, supplementing the low-fat milk used in cheeses making with fat mimetic including Kappa Carrageenan, locust bean and Xanthan gums led to higher scores on the evaluated attributes due to the moisture content enhancement, thereby resulting in a decrease in the differences noted between the sensory evaluation of full and low-fat cheese; Nevertheless, this positive effect of fat replacers was more noticeable and significant during the ripening period than it was during the first day. During the ripening, total quality of scores increased significantly in all cheeses whether controlled or treated but with different rates, this enhancement could be attributed to chemical changing and texture enhancing during the ripening of Domiati cheese $[14,34,40]$. Considering fats content, full-fat cheese kept its evaluation higher than the control low-fat cheese during all the ripening period and showed significant differences value at 75 days of ripening as similar results were obtained by Madadlou et al. [8] who reported that lowfat White cheeses received lower flavour and texture cores than fullfat cheeses. Nevertheless, cheeses with fat replacers showed surprising increase in sensory evaluation and scored the highest increasing rates during the ripening period. This increase resulted in higher significant sensory evaluation as compared with same cheeses without fat replacers. Moreover, the sensory evaluations of these treatments were very close to those in full-fat cheese. It is very important to declare that the mixture of locust bean and didn't produce any off-flavour or bitterness in cheeses during storage and all treatments were highly accepted products to the panellists. The improvement effects of fat replacers and hydrocolloids on sensory characteristics of different varieties of low-fat chees have been previously observed $[4,6,14,25,28,39]$. Using hydrocolloids such as Kappa Carrageenan or Xanthan gums could balance the fat reduction defects $[13,43]$.

\section{Conclusion}

Reducing fat in cheese milk and the addition of different hydrocolloids as fat replacers (including Kappa carrageenan, locust bean and Xanthan gums), did affect the low-fat Domiati cheese in different ways during 75 days of ripening. The incorporation of hydrocolloids into cheeses had a positive effect on low-fat cheeses where it resulted in significant increases in moisture content, protein content and cheeses yield. Moreover, the sensory evaluation for fresh and during the ripening period showed that using selected hydrocolloids as fat replacers could increase the similarity between full and low-fat Domiati cheese. Finally, through the implementation of the conventional protocol to produce Domiati cheese by using low-fat milk and using hydrocolloids as fat mimetic, production of high quality lowfat Domiati cheese was successfully achieved where not only the absence of significant yield reduction was noted, but also the characteristics of full-fat cheese was well preserved. Thereby achieving the objective of meeting both the consumers need and the manufactures demands

\section{Acknowledgement}

The authors are gratefully acknowledged Dr. Ola Nada (Alxandria University,
Egypt) and Dr. Ahmed El Ghannam (Damanhour University, Egypt) for providing language help during writing this manuscript.

\section{References}

1. Abou-Donia SA (1986) Egyptian domiati soft white pickled cheese. New Zealand J Dairy Sci Technol 21: 167-190.

2. El-Baradei G, Delacroix-Buchet AS, Ogier JC (2007) Biodiversity of bacterial ecosystems in traditional egyptian Domiati cheese down-pointing small open triangle. Appl Environ Microbiol 73: 1248-1255

3. Zhang X, Kilmer RL, Muhammad A (2003) A descriptive analysis of Egypt and Saudi Arabia who import United States dairy products. University of Florida International Agricultural Trade and Policy Center.

4. Kavas G, Oysun G, Kinik O, Uysal H (2004) Effect of some fat replacers on chemical, physical and sensory attributes of low-fat white pickled cheese. Food Chem 88: 381-388.

5. Liu H, Xu XM, Guo SD (2008) Comparison of full-fat and low-fat cheese analogues with or without pectin gel through microstructure, texture, rheology, thermal and sensory analysis. Int J Food Sci Technol 43: 1581-1592.

6. Romeih EA, Michaelidou A, Biliaderis CG, Zerfiridis GK (2002) Low-fat whitebrined cheese made from bovine milk and two commercial fat mimetics: chemical, physical and sensory attributes. Int Dairy J 12: 525-540.

7. Johnson ME, Kapoor R, McMahon DJ, McCoy DR, Narasimmon RG, et al (2009) Reduction of sodium and fat levels in natural and processed cheeses: Scientific and technological aspects. Comp Rev Food Sci Food Safe 8: 252 268.

8. Madadlou A, Khosroshahi A, Mousavi ME (2005) Rheology, microstructure, and functionality of low-fat Iranian white cheese made with different concentrations of rennet. J Dairy Sci 88: 3052-3062.

9. Koca N, Metin M (2004) Textural, melting and sensory properties of low-fat fresh kashar cheeses produced by using fat replacers. Int Dairy J 14: 365-373.

10. Sattar MU, Sameen A, Huma N, Shahid M (2015) Exploit fat mimetic potential of different hydrocolloids in low-fat mozzarella cheese. J Food Nutri Res 3 518-525.

11. Lipp M, Anklam E (1998) Review of cocoa butter and alternative fats for use in chocolate-Part A. Compositional data. Food Chem 62: 73-97.

12. Saha D, Bhattacharya $S$ (2010) Hydrocolloids as thickening and gelling agents in food: a critical review. J Food Sci Technol 47: 587-597.

13. Totosaus A, Guemes-Vera N (2008) Effect of $k$ - and $\lambda$-Carrageenans as fatreplacers in low-fat oaxaca cheese. International J Food Prop 11: 656-668.

14. Abd Elhamid AM (2013) Influence of carboxy methyl cellulose on the physicochemical, rheological and sensory attributes of a low-fat Domiati cheese. Int J Dairy Technol 66: 505-511.

15. McMahon DJ, Alleyne MC, Fife RL, Oberg CJ (1996) Use of fat replacers in low-fat mozzarella cheese. J Dairy Sci 79: 1911-1921.

16. Hanáková Z, Buňka F, Pavlínek V, Hudečková L, Janiš R, et al. (2013) The effect of selected hydrocolloids on the rheological properties of processed cheese analogues made with vegetable fats during the cooling phase. Int $J$ Dairy Technol 66: 484-489.

17. Jana AH, Patel HG, Suneeta P, Prajapati JP (2010) Quality of casein based Mozzarella cheese analogue as affected by stabilizer blends. J food Sc Technol 47: 240-242.

18. Černíková M, Buňka F, Pospiech M, Tremlová B, Hladká K, et al. (2010) 
Citation: Alnemr T, Helal A, Hassan A, Elsaadany K (2016) Utilizing the Functions of Hydrocolloids as Fat Mimetic to Enhance the Properties of Lowfat Domiati Cheese. J Food Process Technol 7: 637. doi: 10.4172/2157-7110.1000637

Replacement of traditional emulsifying salts by selected hydrocolloids in processed cheese production. Int Dairy J 20: 336-343.

19. Abou-Donia SA (2008) Origin, history and manufacturing process of Egyptian dairy products: An overview. Alexandria J Food Sci Technol 5: 12

20. AOAC (2000) Official methods of analysis of AOAC International. Official methods of analysis of AOAC International.

21. James CS (1995) Analytical chemistry of foods. Chapman and Hall, Glasgow UK.

22. Johnson ME, Chen CM, Jaeggi JJ (2001) Effect of rennet coagulation time on composition, yield, and quality of reduced-fat cheddar cheese. J Dairy Sci 84 : 1027-1033.

23. Abdou S, Abd-El-Hamid L, Dawood A, Youssef A, Mahran G, et al. (1977) Studies on cephalotyre "Ras" cheese coating. II. Effect on ripening. Egypt J Dairy Sci 5: 191-195.

24. Rudan MA, Barbano DM, Yun JJ, Kindstedt PS (1999) Effect of fat reduction on chemical composition, proteolysis, functionality, and yield of Mozzarella cheese. J Dairy Sci 82: 661-672.

25. Zalazar CA, Zalazar CS, Bernal S, Bertola N, Bevilacqua A et al. (2002) Effect of moisture level and fat replacer on physicochemical, rheological, and sensory properties of low-fat soft cheeses. Int Dairy J 12: 45-50.

26. Madadlou A, Khosroshahi A, Mousavi SM, Djome ZE (2006) Microstructure and rheological properties of Iranian white cheese coagulated at various temperatures. J Dairy Science 89: 2359-2364.

27. Madadlou A, Mousavi ME, Khosrowshahi Asl A, Emam-Djome Z, Zargaran M et al. (2007) Effect of cream homogenization on textural characteristics of lowfat Iranian White cheese. Int Dairy J 17: 547-554.

28. Korish M, Abd Elhamid AM (2012) Improving the textural properties of Egyptian kariesh cheese by addition of hydrocolloids. Int J Dairy Technol 65: 237-242.

29. Michaelidou A, Katsiari MC, Voutsinas LP, Kondyli E (2003) Effect of commercial adjunct cultures on proteolysis in low-fat Kefalograviera-type cheese. Int Dairy J 13: 743-753.

30. Azarnia S, Ehsani MR, Mirhadi SA (1997) Evaluation of the physico-chemical characteristics of the curd during the ripening of Iranian brine cheese. Int Dairy J 7: 473-478.

31. Upreti P, Metzger LE (2007) Influence of calcium and phosphorus, lactose, and salt-to-moisture ratio on cheddar cheese quality: $\mathrm{pH}$ changes during ripening. J Dairy Sci 90: 1-12

32. McSweeney PLH (2004) Biochemistry of cheese ripening. Int J Dairy Techno 57: $127-144$

33. Abdel-kader YI (2003) Changes in the nitrogen fractions of domiati cheese made with microbial and recombinant rennet's during ripening. Egypt $\mathrm{J}$ Dairy Sci 31: 111-116.

34. El-sheikh M, Farag M, Sherin N, El-Shibiny S (2001) Low-fat domiati cheese with particulated whey protein concentrate. Egypt J Dairy Sci 29: 331-337.

35. Van Boekel MAJS (1994) Transfer of milk components to cheese. Scientific considerations, in IDF Seminar on cheese yield and factors affecting its control, Brussels, Belgium pp: 19-28.

36. Mistry VV (2001) Low-fat cheese technology. Int Dairy J 11: 413-422.

37. Mahmoud SF (1995) Studies on low-fat cheese. Menofiya University, Egypt.

38. Van Dijk HJM, Walstra P (1986) Syneresis of curd. One dimensional syneresis of rennet curd in constant conditions. Netherland Milk Dairy J 40: 3-30 .

39. Drake MA, Boylston TD, Swanson BG (1996) Fat mimetics in low-fat cheddar cheese. J Food Sci 61: 1267-1271.

40. Kebary K, Hamed Al, Zedan AN, El-Beheary AAF (2006) Manufacture of lowfat domiati cheese using novage ${ }^{\circledR}$. Egypt J Dairy Sci 34: 175-184.

41. Mehanna NM, Alahwal RIH, Al-Khamy AF (2002) The use of recombinant chymosin in making Domiati cheese. Egypt J Dairy Sci 30: 191-196.

42. Sipahioglu O, Alvarez VB, Solano-Lopez C ((1999) Structure, physico-chemica and sensory properties of feta cheese made with tapioca starch and lecithin as fat mimetics. Int Dairy J 9: 783-789.

43. Zisu B, Shah NP (2005) Textural and functional changes in low-fat Mozzarella cheeses in relation to proteolysis and microstructure as influenced by the use of fat replacers, pre-acidification and EPS starter. Int Dairy J 15: 957-972. 